Sains Malaysiana 49(11)(2020): 2659-2665

http://dx.doi.org/10.17576/jsm-2020-4911-05

\title{
Pembangunan Biopenderia Enzim berasaskan Kolinasterase untuk Mengesan Kehadiran Bahan Cemar Seperti Racun Serangga dan Logam Berat
}

(Enzymatic Biosensor Development based on Cholinesterase in Detecting the Presence of Toxic Substances such as Insecticides and Heavy Metals)

\author{
MOHD KHALiZAN SABULlaH*
}

\section{ABSTRAK}

Bioteknologi merupakan cabang ilmu yang semakin berkembang seiring dengan kemajuan sesebuah negara. Malaysia juga tidak ketinggalan kerana kesedaran dalam bidang ini bakal memberi impak positif sejajar dengan pembangunan kesemua sektor dalam negara seperti pertanian, perikanan, industri pembuatan, makanan, kesihatan dan kelestarian alam sekitar. Oleh itu, pendedahan ilmu bioteknologi wajar diperluaskan daripada setiap peringkat umur bagi menanam minat dan mampu melahirkan ramai pakar dalam bidang ini. Biopenderia merupakan salah satu cabang bioteknologi yang semakin mendapat perhatian oleh kerana penggunaannya yang terbukti berkesan, cepat, murah dan tidak memerlukan kepakaran yang khusus untuk pengendalian. Dalam konteks ini, pengetahuan mengenai bidang bioteknologi melalui pengaplikasian biopenderia mudah disampaikan dan dapat menjana idea, penciptaan dan inovasi yang baharu pada masa akan datang. Ulasan ini membincangkan asas pengetahuan biopenderia menggunakan kolinasterase sebagai contoh yang berfungsi dalam mengesan kehadiran bahan toksik dalam sesuatu medium terutamanya air. Selain itu juga, kaedah pengendalian biopenderia turut dibincangkan secara terperinci berserta perbandingan dengan kaedah konvensional yang berkos tinggi, mengambil masa yang lama untuk penjanaan data dan memerlukan kepakaran teknikal. Kekangan ini menjadikan biopenderia sebagai kaedah alternatif yang terbukti lebih sensitif untuk mengesan kehadiran bahan toksik seperti racun serangga dan logam berat dalam alam sekitar.

Kata kunci: Asai Ellman; asetilkolinasterase; biopenderia; bioteknologi; perencat

\section{ABSTRACT}

Biotechnology is a growing branch of knowledge as a country progress. Malaysia is moving forward due to the awareness in this area that will have a positive impact in line with the development of all sectors in the country such as agriculture, aquaculture, manufacturing industry, food, health, and environmental sustainability. Therefore, exposure to biotechnology should be broadened at every age to nurture interest and will be able to produce many experts in the field. Biosensor is one of the branches of biotechnology that is gaining popularity as its applications are proved to be effective, fast, inexpensive, and do not require specific expertise in its operations. In this context, the knowledge in biotechnology through the application of biosensor is easy to convey and may generate new ideas, inventions, and innovations in the future. This review discusses the basic knowledge of biosensor using cholinesterase as an example in detecting the presence of toxic substances in a medium, especially water. Besides, the operational methods of biosensors was also discussed in detail as well as its comparison with conventional methods that are high costs, require longer time for data generation and high technical expertise. These constrains made biosensor serves as an alternative method that proven more sensitive in detecting the presence of toxic substances such as insecticides and heavy metals in the environment.

Keywords: Acetylcholinesterase; biosensor; biotechnology; Ellman assay; inhibitor

\section{PENGENALAN}

Bioteknologi merupakan kajian sesuatu organisma hidup seperti tumbuhan, haiwan dan mikroorganisma melalui pemerhatian ke atas proses dan sistem biologi untuk dijadikan teknologi bagi penghasilan sesuatu produk atau menambah keberkesanan sesuatu sistem rawatan sama ada secara khusus ataupun tidak langsung. Bioteknologi adalah penting kerana perkembangan bidang ini seiring dengan pembangunan sesebuah negara. Aplikasi daripada kajian bioteknologi memberikan impak yang positif dari segi kos penyelengaraan yang murah, tidak memerlukan masa yang panjang dan tidak memerlukan ruang yang besar 
untuk pelaksanaannya. Biopenderia ataupun istilah bahasa Inggerisnya biosensor merupakan salah satu cabangan bioteknologi. Memandangkan biopenderia memenuhi kriteria yang ada dalam bioteknologi, ia secara tidak langsung menarik perhatian bukan sahaja dalam bidang akademik tetapi juga dalam pelbagai industri seperti pembuatan, pertanian dan kesihatan.

Biopenderia merupakan peranti analisis yang terdiri daripada komponen biologi seperti biomolekul, antigen, antibodi monoklonal atau poliklonal, reseptor sel dan mikroorganisma yang mampu mengesan kehadiran analit tertentu secara kualitatif, kuantitatif atau semikuantitatif. Pengukuran tindak balas biologi atau kimia akan menghasilkan isyarat elektrik yang berkadar langsung dengan kepekatan analit dalam tindak balas tersebut. Analit adalah bahan seperti glukosa yang perlu dikesan oleh sistem biopenderia manakala molekul yang berinteraksi secara khusus dengan analit dikenali sebagai bioreseptor yang terdiri daripada komponen biologi dan biomolekul. Interaksi antara analit dan bioreseptor akan menghasilkan isyarat output sama ada dalam bentuk perubahan warna, cahaya, $\mathrm{pH}$, suhu, cas atau berat, dan kesemua isyarat tersebut dikenali sebagai biopengecaman. Alat pengesan atau transduser akan mengubah biopengecaman tersebut kepada isyarat yang yang boleh diukur dan berfungsi dengan cara fizik-kimia seperti optik, piezoelektrik, elektrokimia dan elektrokimiluminesen yang biasanya berkadar dengan jumlah interaksi analit-bioreseptor. Penggunaan biopenderia semakin meluas terutamanya dalam bidang bioperubatan seperti pemantauan rawatan dan perkembangan penyakit, ujian kehamilan, penemuan ubat, kanser, pengesanan bahan cemar, mikroorganisma penyebab penyakit dan penanda yang merupakan penunjuk penyakit dalam cairan tubuh (darah, air kencing, air liur, peluh), dan juga bidang ketenteraan seperti biokeganasan (D'Souza 2001). Biopenderia juga turut diaplikasikan dalam penentuan kualiti produk berasaskan makanan, lebih-lebih lagi pengesanan patogen bawaan makanan seperti bakteria, virus, parasit dan toksin yang menjadi kebimbangan kerana berkaitan dengan penyakit manusia dan boleh menyebabkan kematian.

Penggunaan dan populariti biopenderia agak pesat sejak beberapa dekad yang lalu sama ada pada peringkat penyelidikan dan pembangunan produk. Hal ini demikian disebabkan terutamanya oleh: perkembangan teknologi mikrofabrikasi dan miniaturisasi, penggunaan molekul biopengecaman yang baharu, kewujudan bahan termaju bersaiz nano dan alat pengesan berstruktur nano yang baharu dan interaksi yang berkesan antara penyelidik sains hayat dan sains fizikal. Pelbagai teknik boleh digunakan untuk pembangunan biopenderia. Gandingan peranti dengan biomolekul berafiniti tinggi mampu menambah pengesanan yang lebih sensitif dan selektif untuk pelbagai jenis analisis. Adalah menjadi kebiasaan faktor pengesan atau penderia biologi terdiri daripada biomolekul seperti karbohidrat, lemak, asid nukleik dan protein khususnya enzim, reseptor dan antibodi yang telah didapati pada mikroorganisma, tumbuhan, haiwan mahupun manusia. Contoh aplikasi biopenderia yang biasa ialah mengesan kehadiran glukosa dalam darah kerana penggunaannya semakin meluas dan meningkat dalam pasaran dunia dari semasa ke semasa (Malhotra et al. 2005; Taguchi et al. 2014) berjaya membangunkan biopenderia bagi mengesan kehadiran formalin dalam ikan kerana sebatian ini bertindak sebagai pengawet oleh para nelayan dan pembekal ikan untuk mengekalkan kesegaran dengan mengelak kerosakan dan pereputan akibat daripada aktiviti mikrob. Bontidean et al. (2004) memanipulasikan bakteria Escherichia coli dan benih Phaseolus vulgaris cv. Limburgse vroege untuk memantau kualiti tanah kebun sayur yang mengandungi kepekatan merkuri yang merencatkan pertumbuhan tanaman di kawasan tersebut.

Selain itu, biopenderia turut diaplikasikan untuk memantau alam sekitar dengan menggunakan enzim protease dan asetilkolinasterase untuk mengesan kehadiran bahan cemar seperti racun perosak, logam berat dan sebatian yang toksik dalam sungai atau sesuatu sampel air (Baskaran et al. 2013; Hayat et al. 2016; Sabullah et al. 2015a).

\section{BIOPENDERIA BERASASKAN KOLINASTERASE}

Sebagai langkah awal untuk memahami biopenderia, enzim adalah calon terbaik untuk diketengahkan. Telah pun diketahui fungsi enzim sebagai pemangkin untuk mempercepatkan tindakbalas ke atas substrat yang khusus untuk menghasilkan produk. Kolinasterase dijadikan contoh biopenderia kerana kajian berkenaan enzim tersebut semakin meningkat dari tahun ke tahun (Hayat et al. 2016). Kolinasterase terbahagi kepada dua iaitu asetilkolinasterase (ACHE) dan butirilkolinasterase. Perbezaan antara kedua-dua jenis enzim ini adalah dari segi substrat; asetilkolinasterase lebih cekap dalam menghidrolisis asetilkolin daripada butirilkolin, manakala butirilkolinasterase menghidrolisis butirilkolin lebih cepat berbanding asetilkolin. Selain itu, oleh kerana enzim ini banyak terdapat di otak terutama di lekah sinaps, asetilkolinasterase memainkan peranan yang penting dalam fungi sistem saraf sementara butirilkolinasterase terkumpul di hati yang bertindak untuk penyahtoksikan terutamanya yang melibatkan agen saraf (Sabullah et al. 2015a). Walau bagaimanapun, kedua-dua enzim tersebut boleh dimanipulasikan untuk menjadi biopenderia yang berbeza dari segi kesensitifannya. Contohnya, asetilkolinasterase sangat sensitif untuk mengesan ketoksikan racun serangga seperti karbamat dan organofosfat, sementara butirilkolinasterase sensitif 
pada pencemaran logam berat (Ahmad et al. 2016a; Tham et al. 2017).

Kolinasterase akan bertindak balas dengan substrat khususnya sama ada asetilkolin diikuti produk yang terhasil adalah asid asetik dan tiokolin. Untuk mengesan kewujudan tindak balas tersebut, hanya kaedah tertentu sahaja yang boleh digunakan yang dikenali sebagai kaedah asai Ellman (Ellman et al. 1961). Asai Ellman memerlukan sebatian yang dinamakan sebagai 5,5-ditiobis (asid 2-nitrobenzoik) atau DTNB yang bertindak sebagai kromogen untuk mengesan metabolisasi asetilkolinasterase ke atas asetiltiokolin dengan menghasilkan warna kuning cerah setelah tindak balas berlaku antara produk tiokolin dan DTNB (Rajah 1).

Tabung uji

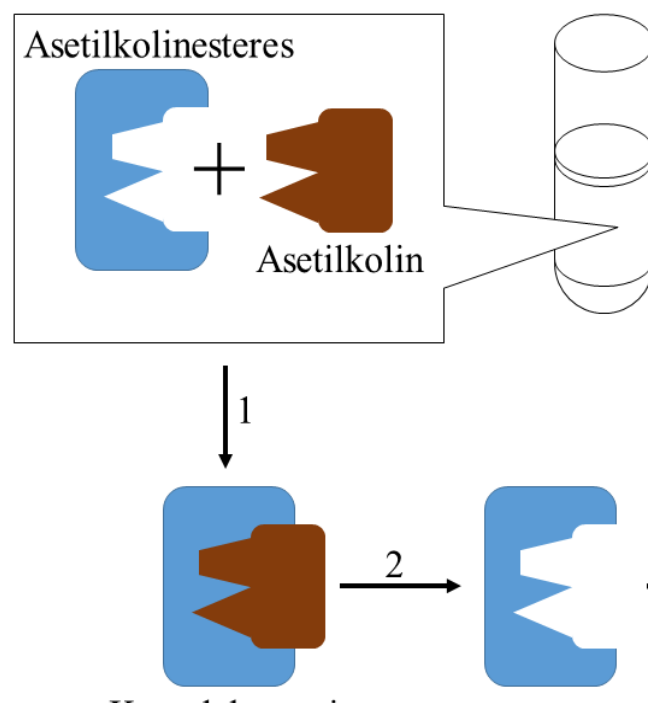

Kompleks enzim substrat

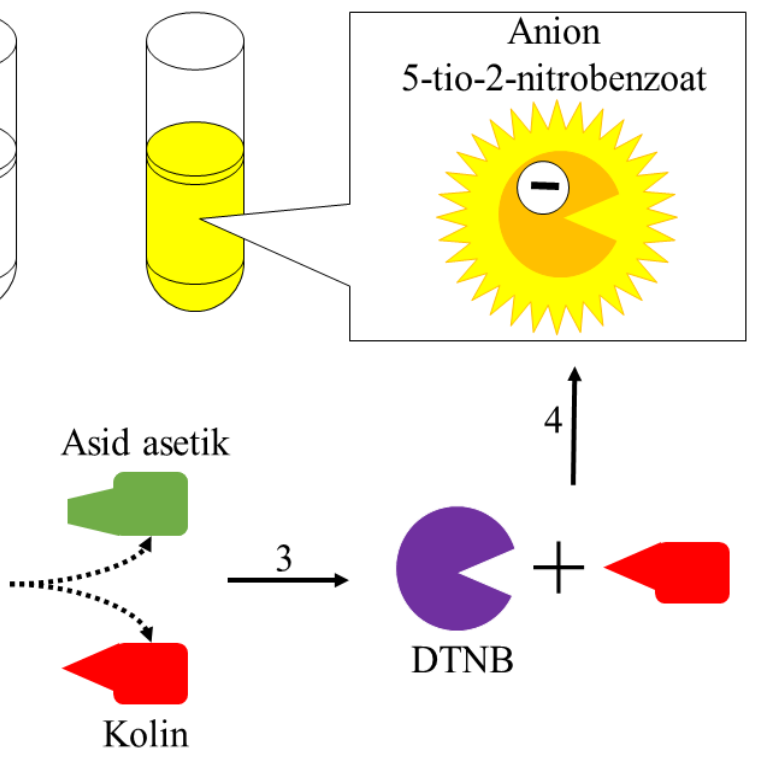

RAJAH 1. Tabung uji yang mengandungi campuran enzim asetilkolinesteres, substrat asetilkolin dan kromogen DTNB 1) tindak balas menunjukkan pembentukan kompleks enzim-substrat diikuti 2) produk akhir tindak balas menghasilkan asid asetik dan kolin. 3) Hanya kolin akan bertindak balas untuk menurunkan DTNB kepada 4) pembentukan anion 5-tio-2-nitrobenzoat yang menyebabkan campuran menjadi kuning cerah berbanding dengan sebelumnya yang tidak berwarna. $\odot$ menandakan 5-tio-2-nitrobenzoat telah diturunkan kepada bercas negatif

Sebaliknya, kehadiran perencat akan menghalang pembentukan enzim kompleks dan turut menyebabkan tiada pembentukan warna kuning tersebut atau kurang bergantung kepada jenis dan kepekatan perencat (Rajah 2). Racun serangga dan logam berat dikategorikan sebagai perencat untuk enzim asetilkolinasterase dan juga merupakan agen yang boleh menyebabkan pencemaran alam sekitar terutamanya sungai yang merupakan sumber air utama negara.

Dalam konteks biopenderia, enzim asetilkolinasterase dimanipulasikan fungsinya sebagai pengesan biologi untuk kehadiran bahan cemar tersebut. Hidupan akuatik merupakan sumber terbaik asetilkolinasterase kerana mudah didapati di samping sensitif terhadap pelbagai jenis ketoksikan. Sebagai contoh, hasil kajian Tham et al. (2009), Sabullah et al. (2015b) dan Ahmad et al. (2016a) masing-masing membuktikan asetilkolinasterase daripada ikan tempatan seperti ikan keli, ikan lampam jawa dan ikan puyu mempunyai kesensitifan yang tinggi dan berpotensi sebagai alat biopenderia untuk menentukan tahap pencemaran dalam air. 


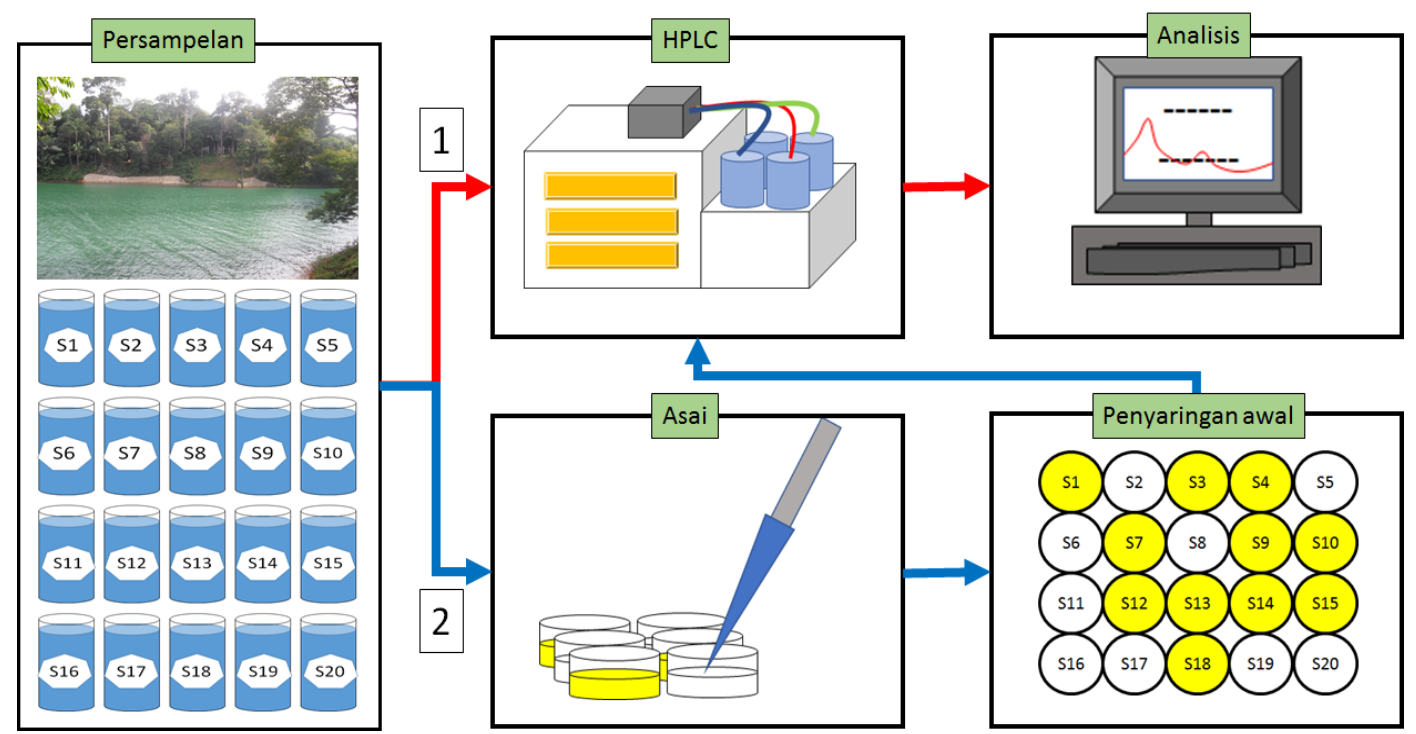

RAJAH 2. Kehadiran substrat asetilkolin dan perencat akan mewujudkan situasi seperti berikut: 1) Kesemua asetilkolin berjaya membentuk kompleks enzim-substrat dan dimetabolisasikan dengan terbentuknya warna kuning cerah, 2) kesemua perencat memenuhi kesemua tapak aktif asetilkolinesteres menyebabkan kegagalan asetilkolin untuk dimetabolisasikan dan tiada pembentukan warna kuning, dan 3) sebahagian asetilkolin dimetabolisasikan sementara sebahagian perencat melekat pada tapak aktif asetilkolinesteres dan keputusannya hanya sedikit warna kuning pucat terhasil

\section{KELEBIHAN DAN KAEDAH PENGAPLIKASIAN BIOPENDERIA KOLINASTERASE}

Kebiasaannya, kadar pencemaran sesuatu sampel air ditentukan dengan menggunakan teknologi moden seperti kromatografi cecair prestasi tinggi (HPLC) dan plasma pasangan induktif (ICP), dengan penggunaannya secara jelas terlalu mahal dan memakan masa yang lama untuk beroperasi di samping sukar dialih. Sebagai langkah alternatif, biopenderia boleh dijadikan salah satu prosedur untuk penyaringan awal bagi menentukan kehadiran bahan cemar dalam sesuatu sampel. Tambahan lagi, dengan kewujudan beberapa alatan yang semakin canggih serta mampu menganalisis data secara kualitatif, semi kuantitatif mahupun kuantitatif, maka data dan

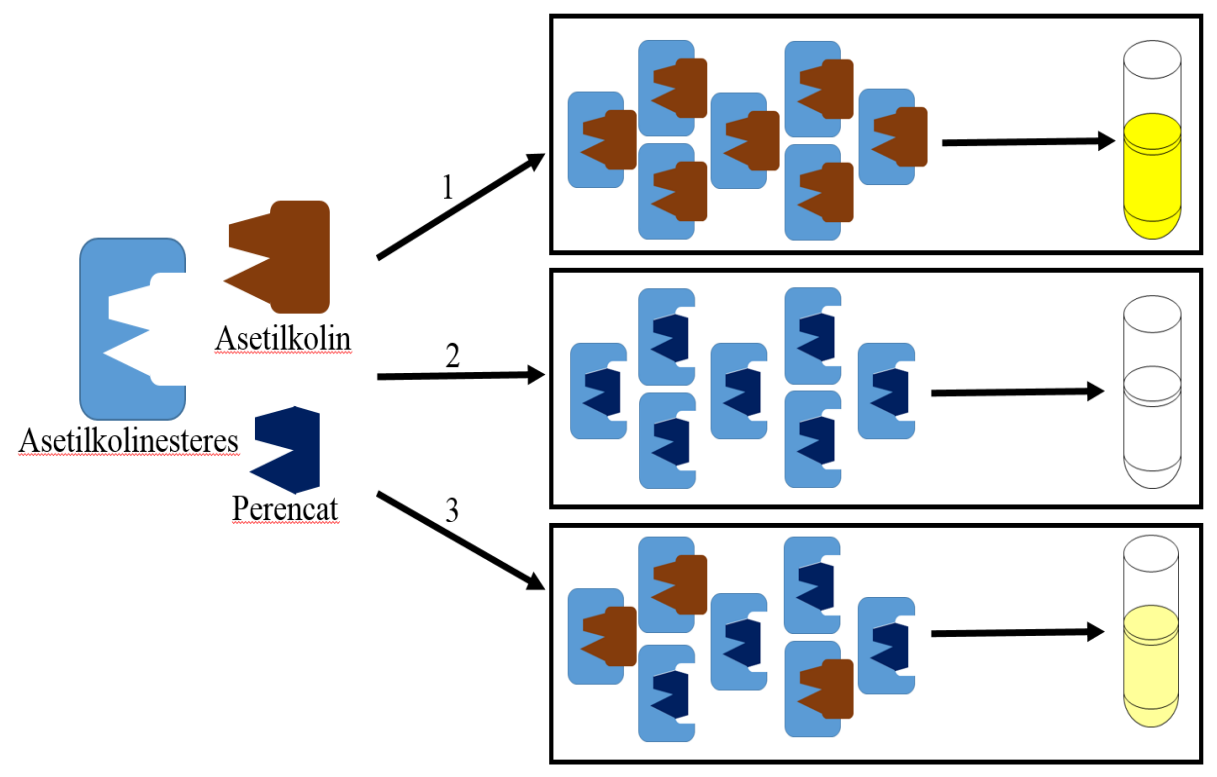

RAJAH 3. Dua contoh penentuan tahap pencemaran bagi setiap sampel air sungai bertanda S1 sehingga S20. Laluan 1 berwarna merah menunjukkan kesemua sampel tersebut terus diuji menggunakan teknologi moden iaitu HPLC dan seterusnya analisis untuk penentuan jumlah kuantiti bahan cemar. Laluan 2 berwarna biru menunjukkan kesemua sampel diasai dengan kaedah Ellman dan disaring peringkat awal. Hanya sampel yang menunjukkan perencatan ketara ke atas aktiviti asetilkolinesteres akan diteruskan untuk saringan kedua menggunakan HPLC diikuti analisis kuantitatif dan pengecaman ke atas bahan cemar di dalam sampel 
keputusan analisis mampu dijana dengan lebih cepat walaupun kaedah biopenderia ini hanyalah digunakan untuk penyaringan peringkat awal (Jamadon et al. 2018). Rajah 3 menunjukkan contoh kaedah mengesan bahan cemar iaitu secara terus menggunakan HPLC (laluan 1 berwarna merah) dan kaedah gabungan dimulakan dengan penggunaan biopenderia iaitu asai Ellman diikuti penyaringan dan penentuan kepekatan melalui analisis HPLC (laluan 2 berwarna biru).

Merujuk kepada laluan 1, kesemua 20 sampel air dari pelbagai sungai ditentukan terus melalui HPLC. Jika ujian ke atas satu sampel berharga RM100.00 (anggaran harga khas perkhidmatan untuk institusi kerajaan yang telah ditetapkan oleh Institut Biosains, UPM, 2015), maka jumlah kesemuanya ialah RM2000.00. Dibandingkan dengan laluan 2, setiap sampel air tersebut akan melalui penyaringan awal menggunakan biopenderia. Seterusnya, hanya sampel yang positif (sampel yang menunjukkan perencatan ke atas enzim melalui assai Ellman) akan dipilih untuk penyaringan kedua bagi menentukan jumlah kepekatan bahan cemar dalam sampel. Anggaran harga bagi satu asai ialah RM5.00 (anggaran harga khas ujian ELISA untuk institusi kerajaan yang telah ditetapkan oleh
Institut Biosains, UPM, 2015) dan jumlah keseluruhan ialah RM100.00. Rajah 3 menunjukkan contoh hanya 10 sampel yang dipilih untuk saringan kedua dengan jumlah perbelanjaan sebanyak RM1000.00. Dengan jumlah perbelanjaan sebanyak RM1100.00, maka kaedah ini telah terbukti memberikan penjimatan sebanyak RM900.00 jika dibandingkan dengan kaedah konvensional (Rajah 3). Ini merupakan salah satu kelebihan biopenderia kerana prosesnya mudah, murah, menjimatkan masa yang hanya memerlukan tempoh inkubasi sekitar 20 minit dan pengujiannya boleh dilakukan dengan serentak (Ahmad et al. 2016a; Aidil et al. 2013; Hayat et al. 2016; Sabullah et al. 2014).

\section{BAHAN MENTAH ALTERNATIF DAN PRODUK BIOPENDERIA BUATAN MALAYSIA}

Kepelbagaian bio di Malaysia mampu menyediakan bahan mentah yang berfungsi untuk kesejahteraan masyarakat setempat. Ini selari dengan beberapa penemuan khususnya dalam mengembangkan pengaplikasian biopenderia berasaskan kolinasterase yang diekstrak daripada sumber hidupan akuatik tempatan yang terbukti setanding di peringkat global (Jadual 1).

JADUAL 1. Sumber tempatan yang dikenal pasti kemampuannya untuk mengesan kehadiran bahan tercemar seperti logam berat, agen saraf dan racun serangga seperti karbamat dan organofosfat

\begin{tabular}{|c|c|c|c|}
\hline $\begin{array}{l}\text { Sumber } \\
\text { (Nama Tempatan) }\end{array}$ & Kesensitifan (Organ) & Kaedah & Rujukan \\
\hline $\begin{array}{l}\text { Clarias batracus } \\
\text { (Ikan Keli) }\end{array}$ & $\begin{array}{l}\text { Karbaril dan karbofuran merencat lebih } \\
90 \% \text { aktiviti asetilkolinesteres. (Otak) }\end{array}$ & Kolorimetri & $\begin{array}{l}\text { Tham et al. } \\
(2009)\end{array}$ \\
\hline $\begin{array}{l}\text { Anabas testudineus } \\
\text { (Ikan Puyu) }\end{array}$ & $\begin{array}{l}\mathrm{As}^{5+}, \mathrm{Cd}^{2+}, \mathrm{Co}^{2+}, \mathrm{Cr}^{6+}, \mathrm{Cu}^{2+}, \mathrm{Hg}^{2+} \text { and } \mathrm{Ni}^{2+} \\
\text { mampu merencat lebih dari } 50 \% \text { aktiviti } \\
\text { butirilkolinesteres. (Hati) }\end{array}$ & Kolorimetri & $\begin{array}{l}\text { Ahmad et al. } \\
(2016 b)\end{array}$ \\
\hline $\begin{array}{l}\text { Pangasius hypophthalmus } \\
\text { (Ikan Patin) }\end{array}$ & $\begin{array}{l}\mathrm{IC}_{50} \text { bagi setiap logam berat seperti } \mathrm{Hg}^{2+} \text {, } \\
\mathrm{Cu}^{2+}, \mathrm{Ag}^{2+}, \mathrm{Cr}^{6+}, \mathrm{Cd}^{2+}, \mathrm{Pb}^{2+}, \text { dan } \mathrm{Zn}^{2+} \\
\text { masing-masing ialah } 0.071,0.088,0.088 \text {, } \\
0.87,0.913,1.1 \text {, and } 1.572 \mathrm{mg} / \mathrm{L} .(\text { Otak })\end{array}$ & Kolorimetri & $\begin{array}{l}\text { Aidil et al. } \\
(2013)\end{array}$ \\
\hline $\begin{array}{l}\text { Puntius javanicus } \\
\text { (Ikan Lampam Jawa) }\end{array}$ & $\begin{array}{l}\mathrm{IC}_{50} \text { bagi setiap racun serangga seperti } \\
\text { karbofuran, karbaril, bendiokarp, propoxur, } \\
\text { metomil, malation, diazinon, parathion } \\
\text { dan klorpirifos masing-masing ialah } 0.035 \text {, } \\
0.031,0.045,0.076,0.090,0.063,0.103 \text {, } \\
0.151 \text { and } 0.202 \mathrm{mg} / \mathrm{L} \text {. (Otak) }\end{array}$ & Kolorimetri & $\begin{array}{l}\text { Sabullah et } \\
\text { al. (2014) }\end{array}$ \\
\hline $\begin{array}{l}\text { Lates calcarifer } \\
\text { (Ikan Siakap) }\end{array}$ & $\begin{array}{l}\mathrm{IC}_{50} \text { bagi plumbum ialah } 0.1 \mathrm{ppm} \text {. (Buah } \\
\text { pinggang) }\end{array}$ & Kolorimetri & $\begin{array}{l}\text { Hayat et al. } \\
(2016)\end{array}$ \\
\hline $\begin{array}{l}\text { Channa striatus } \\
\text { (Ikan Haruan) }\end{array}$ & $\begin{array}{l}\mathrm{IC}_{50} \text { bagi setiap logam berat seperti } \mathrm{Hg}^{2+} \text {, } \\
\mathrm{Ag}^{2+}, \mathrm{Pb}^{2+}, \mathrm{Cu}^{2+} \text { dan } \mathrm{Cr}^{6+} \text { masing-masing } \\
\text { ialah } 0.084,0.100,0.126,0.087 \text {, and } 0.177 \\
\text { mg/L. (Otak) }\end{array}$ & - & $\begin{array}{l}\text { Zulkifli et al. } \\
\text { (2017) }\end{array}$ \\
\hline $\begin{array}{l}\text { Oreochromis mossambica } \\
\text { (Ikan Tilapia) }\end{array}$ & $\begin{array}{l}\mathrm{IC}_{50} \text { bagi agen saraf eserin, propidium, iso- } \\
\text { OMPA dan karbofuran masing-masing ialah } \\
0.441,7.91,0.117 \text { dan } 0.532 \mathrm{ppm} \text {. (Otak) }\end{array}$ & Kolorimetri & $\begin{array}{l}\text { Tham et al. } \\
\text { (2017) }\end{array}$ \\
\hline
\end{tabular}


Sedar atau tidak, beberapa produk biopenderia buatan Malaysia telah pun dibangunkan dan diperkembangan potensinya untuk diaplikasikan secara meluas. Contohnya Eduzyme (2005) yang merupakan salah satu produk tempatan yang telah dipatenkan dan boleh dijadikan modus operandi yang khusus untuk pengajaran di peringkat sekolah, terutamanya dalam kelas amali bagi memudahkan pelajar memahami fungsi enzim dan kesan kewujudan perencat.

Selain itu, Xenoassay (2005) merupakan alat biopenderia alam sekitar yang telah dipatenkan dengan enzim protease dimanipulasikan sebagai pengesan kewujudan bahan toksik dalam sesuatu sampel terutamanya air sungai. Fungsi enzim dalam produk ini sama seperti asetilkolinasterase tetapi berbeza dari segi jenis, sifat dan sumber enzim dan perbezaan kadar kesensitifan terhadap bahan cemar. Penciptaan ini mendapat pengiktirafan dan menarik perhatian luar negara kerana fungsi dan penggunaannya yang mudah, murah, menjimatkan masa dan boleh dipercayai. Buktinya, produk ini telah memenangi pelbagai anugerah seperti anugerah platinum dan pingat emas di Alexandria Palace, sempena 'British Innovation Show (BIS) 2010' manakala di peringkat nasional juga telah mendapat pingat emas sempena pameran PECIPTA '07 di Kuala Lumpur (Shukor et al. 2010, 2007). Oleh yang demikian, kepelbagaian sumber flora dan fauna di Malaysia mungkin dapat menjana idea dan memberi galakan kepada rakyat Malaysia untuk mencipta dan berinovasi sesuatu produk berdasarkan kaedah bioteknologi yang ternyata memberi impak positif dari segi pemprosesan sehingga penghasilan produk yang dijamin kualiti serta kuantitinya.

\section{KESIMPULAN}

Tuntasnya, kepakaran dan perkembangan penggunaan biopenderia wajar dipertingkat dari semasa ke semasa. Ekploitasi enzim kolinesteres sebagai alat biopenderia telah membuktikan keberkesanan dalam mengesan kehadiran bahan-bahan toksik seperti racun perosak dan logam berat. Tidak dinafikan kepelbagaian flora dan fauna di Malaysia memberikan impak yang positif dalam menjalankan penyelidikan bagi menentukan sumber kolinesteres yang terbaik dan paling sensitif sebagai langkah saringan awal sebelum proses penentuan identiti dan kepekatan bahan toksik menggunakan kaedah konvensional seperti HPLC, ICP dan kromatografi gas. Dengan kewujudan beberapa inovasi buatan tempatan yang bertaraf global bukan sahaja boleh diaplikasikan dalam kepelbagaian industri, malah mampu didedahkan kepada semua peringkat umur bagi menanam minat pelajar, justeru menambah kehadiran celik pintar dan pakar dalam bidang ini pada masa akan datang. Pengenalan dan pengajaran melalui aplikasi biopenderia dalam memperkenalkan bioteknologi merupakan alternatif atau pendekatan yang terbaik oleh kerana ia mudah difahami dan dikendalikan di samping matlamatnya jelas dalam pembangunan sesebuah negara.

\section{PENGHARGAAN}

Penghargaan kepada Fakulti Sains dan Sumber Alam, UMS atas kebenaran menggunakan fasiliti dan sebahagian geran oleh Universiti Malaysia Sabah iaitu Skim Geran Dana NIC - SDN0020 - 2019. Ribuan terima kasih ditujukan kepada Prof. Madya Dr. Mohd Yunus Abd. Shukor atas perkongsian maklumat berkenaan produk Eduzyme dan Xenoassay.

\section{RUJUKAN}

Ahmad, S.A., Sabullah, M.K., Shamaan, N.A., Abd Shukor, M.Y., Jirangon, H., Khalid, A. \& Syed, M.A. 2016a. Evaluation of acetylcholinesterase source from fish, Tor tambroides for detection of carbamate. Journal of Environmental Biology 37(4): 479-484.

Ahmad, S.A., Wong, Y.F., Shukor, M.Y., Sabullah, M.K., Yasid, N.A., Hayat, N.M. \& Syed, M.A. 2016b. An alternative bioassay using Anabas testudineus (Climbing perch) colinesterase for metal ions detection. International Food Research Journal 23(4): 1446-1452.

Aidil, M.S., Sabullah, M.K., Halmi, M.I.E., Sulaiman, R., Shukor, M.S., Shukor, M.Y. \& Syahir, A. 2013. Assay for heavy metals using an inhibitive assay based on the acetylcholinesterase from Pangasius hypophthalmus (Sauvage, 1878). Fresenius Environmental Bulletin 22(12): 3572-3576.

Baskaran, G., Masdor, N.A., Syed, M.A. \& Shukor, M.Y. 2013. An inhibitive enzyme assay to detect mercury and zinc using protease from Coriandrum sativum. The Scientific World Journal 2013: 678356.

Bontidean, I., Mortari, A., Leth, S., Brown, N.L., Karlson, U., Larsen, M.M., Vangronsveld, J., Corbisier, P. \& Csöregi, E. 2004. Biosensors for detection of mercury in contaminated soils. Environmental Pollution 131(2): 255-262.

D’Souza, S.F. 2001. Microbial biosensors. Biosensors \& Bioelectronics 16(6): 337-353.

Ellman, G.L., Courtney, K.D., Andres Jr., V. \& Featherstone, R.M. 1961. A new and rapid colorimetric determination of acetylcholinesterase activity. Biochemical Pharmacology 7(2): 88-95.

Eduzyme ${ }^{\circledR}$. 2005. Educational Kit for Teaching Enzyme Works; All Included in Class. Registration No 05003865 (Filed at MIPO: 16/3/05)16/3/2015-class 9).

Hayat, N.M., Shamaan, N.A., Sabullah, M.K., Shukor, M.Y., Syed, M.A., Khalid, A. \& Ahmad, S.A. 2016. The use of Lates calcarifer as a biomarker for heavy metals detection. Rendiconti Lincei 27(3): 463-472.

Institut Biosains, Universiti Putra Malaysia. 2015. Kadar Sewaan Peralatan, Caj Perkhidmatan dan Harga Produk yang Ditawarkan oleh Institut Biosains. http://www.ibs.upm. edu.my/dokumen/INBIO1_Kadar_Sewaan_Alatan_Caj_ Perkhidmatan_Dan_Produk_Di_IBS.pdf.

Jamadon, N.K., Busairi, N. \& Syahir, A. 2018. Smartphone assisted naked eye detection of mercury (ii) ion using 
horseradish peroxidase inhibitive assays. Protein \& Peptide Letters 25: 90-95.

Malhotra, B.D., Singhal, R., Chaubey, A., Sharma, S.K. \& Kumar, A. 2005. Recent trends in biosensors. Current Applied Physics 5(2): 92-97.

Noor Aini, B., Siddiquee, S. \& Ampon, K. 2016. Development of formaldehyde biosensor for determination of formalin in fish samples; Malabar Red Snapper (Lutjanus malabaricus) and Longtail Tuna (Thunnus tonggol). Biosensors 6(3): 32.

Sabullah, M.K., Shukor, M.Y.A., Shamaan, N.A., Khalid, A., Ganzau, A.J., Sulaiman, M.R. \& Ahmad, S.A. 2015a. Purification and anticholinesterase sensitivity of cholinesterase extracted from liver tissue of Puntius javanicus. International Journal of Agriculture and Biology 17(5): 1025-1030.

Sabullah, M.K., Sulaiman, M.R., Shukor, M.S., Yusof, M.T., Johari, W.L.W., Shukor, M.Y. \& Syahir, A. 2015 b. Heavy metals biomonitoring via inhibitive assay of acetylcholinesterase from Periophthalmodon schlosseri. Rendiconti Lincei 26(2): 151-158.

Sabullah, M.K., Sulaiman, M.R., Shukor, M.Y.A., Syed, M.A., Shamaan, N.A., Khalid, A. \& Ahmad, S.A. 2014. The assessment of cholinesterase from the liver of Puntius javanicus as detection of metal ions. The Scientific World Journal 2014: e571094.

Shukor, M.Y., Baskaran G., Sabullah, M.K. \& Syed, M.A. 2010. Multiple Xenoassay Kit for Detecting Environmental Toxicants. British Invention Show (BIS). Alexandria Palace, 13-16th October, London.

Shukor, M.Y., Rahman, M.F.A., Tham, L.G., Othman, A.R., Bakar, N.L., Shamaan, N.A. \& Syed, M.A. 2007. Multiple Xenoassay Kit for detecting Environmental Toxicants. PECIPTA 07 (International Exposition of Research and Inventions of Institutions of Higher Learning 2007). 10 -12
August 2007. Kuala Lumpur Convention Centre, Kuala Lumpur, Malaysia.

Taguchi, M., Ptitsyn, A., McLamore, E.S. \& Claussen, J.C. 2014. Nanomaterial-mediated biosensors for monitoring glucose. Journal of Diabetes Science and Technology 8(2): 403-411.

Tham, L.G., Perumal, N., Ahmad, S.A. \& Sabullah, M.K. 2017. Characterisation of purified acetylcholinesterase (EC 3.1.1.7) from Oreochromis mossambica brain tissues. Journal of Biochemistry, Microbiology and Biotechnology 5(2): 22-27.

Tham, L.G., Perumal, N., Syed, M.A., Shamaan, N.A. \& Shukor, M.Y. 2009. Assessment of Clarias batrachus as a source of acetylcholinesterase (AchE) for the detection of insecticides. Journal of Environmental Biology 30(1): 135-138.

Xenoassay®. 2005. Bioassay System for Assaying Xenobiotics; For Sale in Kit Form; All Included in Class. Registration No 05003866. (Filed at MIPO: 16/3/05)16/3/2015-class 9.

Zulkifli, A.F., Tham, L.G., Perumal, N., Shukor, M.Y. \& Shaharuddin, N.A. 2017. Assay for heavy metals using an inhibitive assay based on the acetylcholinesterase from Channa striatus. Bioremediation Science and Technology Research 5(1): 7-11.

Program Bioteknologi

Fakulti Sains dan Sumber Alam

Universiti Malaysia Sabah

Jalan UMS, 88400 Kota Kinabalu, Sabah

Malaysia

*Pengarang untuk surat-menyurat; email: khalizan@ums.edu.my

Diserahkan: 26 November 2019

Diterima: 18 Mei 2020 